\title{
RESPON PETERNAK TERHADAP PENCEGAHAN DAN PENGOBATAN PENYAKIT CACING GILIG PADA TERNAK KAMBING DI DESA TRACAP KECAMATAN KALIWIRO KABUPATEN WONOSOBO
}

(Farmers Response To Prevention And Medication Goat Nematode Worm Disease At Tracap Village Kaliwiro District Wonosobo Sub-Province.)

\author{
Widiarso, B.P. ${ }^{1}$, Sunarsih $^{2}$ dan $^{\text {Meniati }}{ }^{3}$ \\ ${ }^{1,2)}$ Staf Pengajar Sekolah Tinggi Penyuluhan Pertanian Magelang \\ Jl. Magelang-Kopeng Km 7 Tegalrejo Magelang PO BOX 101 \\ E-mail : budipw2000@yahoo.com \\ ${ }^{3)}$ Fungsional Penyuluhan Pertanian di Kabupaten Kapuas Kalimantan Tengah
}

Diterima : 15 Desember 2014 Disetujui : 25 September 2015

\begin{abstract}
This research was conducted to know farmers respon to prevention and medication goat nematode worm disease and know factor - factor influencing farmer respon to prevention and medication of nematode worm disease. Appliance and used materials that is stationery, questioner, folder, worm drug and vitamin tablet of B complek.Responder amount to 30 people. The data taking away from pre test and post test by interview to hit home prevention and medication goat nemode worm disease by using questioner. Based from couple linear as follows: $Y=28.946+5.084 X 1-0,215 X 2+0,171 X 3+0,548 X 4+e$

From model of regresi above earning and interpreting that each;every make-up of value of X1 ( pendidikan) equal to $1 \%$ will add respon equal to 5.084, each;every make-up of value of X2 ( umur) equal to $1 \%$ will lessen respon equal to 0,215, each;every make-up of value of X3 ( experience of beternak) equal to $1 \%$ will add value of respon equal to 0,171, and each;every make-up of value of X4 (amount of the ownership of livestock) equal to $1 \%$ will add value of 0,548

The result of statistical test as a whole showed that education factor, age, experience of amount and ownership of livestock collectively/together was] same to have an effect on very signifikan to farmers respon to prevention and medication of goat nematode worm disease of that is from low respon become high respon Education represent.

This study was concluded that happened the make-up of knowledge aspect equal to 14,87 with EP 82,6\% and EPP 77,36, attitude aspect equal to 10,47 with EP 90,88\% and EPP 82,12\% and also skill aspect equal to 5,1 with EP 86,6\% and EPP 79,19\% and makeup of value of respon of knowledge aspect, attitude, and skill equal to 30,39\% that is from low respon become high respon to prevention and medication of goat nematode worm disease.
\end{abstract}

Keywords: nematode worm, goat, response

\begin{abstract}
ABSTRAK
Penelitian ini dilakukan untuk mengetahui respon peternak terhadap pencegahan dan pengobatan penyakit cacing gilig pada ternak kambing dan mengetahui faktor - faktor yang mempengaruhi respon peternak terhadap pencegahan dan pengobatan penyakit cacing gilig.
\end{abstract}


Alat dan bahan yang digunakan yaitu alat tulis, kuisioner, folder, EK, obat cacing dan tablet vitamin B komplek.

Responden berjumlah 30 orang. Data di ambil dari pra test dan post test dengan cara melakukan wawancara langsung mengenai pencegahan dan pengobatan penyakit cacing gilig dengan alat bantu kuisioner. Berdasarkan analisis regresi didapatkan persamaan linear berganda sebagai berikut : $\mathrm{Y}=28.946+5.084 \mathrm{X} 1-0,215 \mathrm{X} 2+0,171 \mathrm{X} 3+0,548 \mathrm{X} 4+\mathrm{e}$

Dari model regresi diatas dapat di artikan bahwa setiap peningkatan nilai X1 (pendidikan) sebesar 1\% akan menambah respon sebesar 5.084, setiap peningkatan nilai X2 (umur) sebesar $1 \%$ akan mengurangi respon sebesar 0,215 , setiap peningkatan nilai X3 (pengalaman beternak) sebesar $1 \%$ akan menambah nilai respon sebesar 0,171, dan setiap peningkatan nilai X4 (jumlah kepemilikan ternak) sebesar 1\% akan menambah nilai respon sebesar 0,548 .

Hasil uji statistik secara keseluruhan menunjukan bahwa faktor pendidikan, umur, pengalaman beternak dan jumlah kepemilikan ternak secara bersama - sama berpengaruh sangat nyata atau sangat signifikan terhadap respon peternak terhadap pencegahan dan pengobatan penyakit cacing gilig pada ternak kambing.

Kajian ini disimpulkan bahwa terjadi peningkatan aspek pengetahuan sebesar 14,87 dengan EP 82,6\% dan EPP 77,36\%, aspek sikap sebesar 10,47 dengan EP 90,88\% dan EPP 82,12\% serta aspek keterampilan sebesar 5,1 dengan EP 86,6\% dan EPP 79,19\% dan peningkatan nilai respon dari aspek pengetahuan, sikap, dan keterampilan sebesar 30,39\% yaitu dari respon rendah menjadi respon tinggi terhadap pencegahan dan pengobatan penyakit cacing gilig pada ternak kambing. Pendidikan merupakan faktor yang paling berpengaruh sangat signifikan $0,001 \alpha(\mathrm{P} \leq 0,01)$ terhadap tingkat respon peternak $(5,084)$.

Kata Kunci : Penyakit, cacing gilig, ternak kambing

\section{PENDAHULUAN}

\section{Latar Belakang}

Kebijakan pembangunan pertanian, khususnya pada sektor peternakan, diarahkan untuk meningkatkan pendapatan dan taraf hidup petani melalui produksi peternakan baik dari segi kualitas maupun kuantitas.

Usaha peternakan di Indonesia sampai saat ini masih menghadapi kendala yang mengakibatkan produktifitas ternak masih rendah. Hal ini disebabkan oleh berbagai jenis penyakit sering berjangkit di Indonesia baik menular maupun tidak menular, penyakit yang biasanya bisa menimbulkan kerugian peternak.

Peningkatkan produktifitas ternak khususnya kambing, maka kesehatan hewan perlu mendapat perhatian, ternak yang sehat dapat berkembangbiak dengan baik dan produktifitasnya meningkat. Penyakit sangat mempengaruhi pertumbuhan ternak, oleh karena itu kita harus melakukan pencegahan dan pengobatan terhadap ternak agar ternak yang di pelihara dapat tumbuh sehat dan berkembang tanpa ada penyakit yang di derita oleh ternak. Seperti penyakit yang di sebabkan oleh parasit ( penyakit cacing gilig ). Penyakit yang ini banyak terjangkit pada ternak ruminansia yang mengakibatkan pertumbuhan ternak lambat dan produktifitas menurun.(Subekti et al, 1996)

Komoditas peternakan kambing memiliki peluang untuk di kembangkan. Kambing adalah salah satu ternak popular yang banyak dipelihara di kalangan peternak di pedesaan. Ternak kambing pemeliharaannya mudah, cepat berkembangbiak, modal yang di perlukan relatif kecil di banding dengan ternak sapi dan kerbau, bisa dipelihara di lahan sempit 
dan fecesnya bisa di manfaatkan sebagai pupuk organik untuk tanaman. Dilihat dari potensinya maka ternak kambing dengan pemeliharaan dan perawatan yang baik akan di peroleh hasil yang baik pula.

Keberhasilan dalam beternak kambing selain faktor bibit, tatalaksana pemeliharaan, perkandangan dan pakan, kesehatan ternak juga harus di perhatikan. Pemeliharaan ternak kambing oleh peternakdi desa Tracap Kecamatan Kaliwiro Kabupaten Wonosobo, ditinjau dari kesehatan ternaknya masih kurang terutama dalam pencegahan dan pengobatan Penyakit cacing gilig. Ternak ternak yang mereka pelihara pada umumnya kurus dan bulunya kusam walaupun cukup pakan.

Di desa Tracap Kecamatan Kaliwiro terdapat 4 (empat) dusun yaitu Dusun Wonoruto, Dusun Tracap, Dusun Jojogan, dan Dusun Cikalan. Masing - masing dusun terdapat kelompok tani diantaranya adalah kelompok tani Wonomaju, Kartika tani, Tunas mukti, Harapan, Cikalsari dan Sari mulyo. Jumlah populasi ternak yang ada di Desa Tracap Kecamatan Kaliwiro,sapi perah sekitar 48 ekor, kambing 1312 ekor, dan domba 286 ekor.

Hasil identifikasi di Desa Tracap Kecamatan Kaliwiro terhadap ternak ternak yang menunjukan tanda - tanda terserang Penyakit cacing gilig sehingga ternak kambing yang di pelihara belum dapat memenuhi harapan peternak yaitu perkembangan tubuh yang maksimal sehinga memiliki nilai jual yang tinggi.

\section{Rumusan Masalah}

Berdasarkan hasil identifikasi di Desa Tracap Kecamatan Kaliwiro Kabupaten Wonosobo terhadap beberapa permasalahan yaitu :
1. Belum diketahui respon peternak terhadap pencegahan dan pengobatan Penyakit cacing gilig pada ternak kambing di Desa Tracap Kecamatan Kaliwiro Kabupaten Wonosobo.

2. Belum diketahui faktor - faktor yang mempengaruhi respon peternak terhadap pencegahan dan pengobatan penyakit cacing pada ternak kambing.

\section{Tujuan Penelitian}

Dilihat dari permasalahan tersebut di atas maka tujuan yang ingin di capai adalah sebagai berikut :

1. Untuk mengetahui respon peternak terhadap pencegahan dan pengobatan penyakit cacing gilig tehadap ternak kambing

2. Untuk mengetahui faktor - faktor yang mempengaruhi respon peternak terhadap pencegahan dan pengobatan Penyakit cacing gilig pada ternak kambing.

\section{MATERI DAN METODE}

\section{Materi}

Materi penelitian ini meliputi alat dan bahan.Bahan yang digunakan adalah obat cacing monil, buah pinang, antibiotik dan tablet vitamin B kompleks. Alat yang digunakan dalam peneltian adalah alat tulis, kuesioner, folder dan Elemen keterampilan (EK)

\section{Metode}

\section{Metode Pengambilan Sampel}

Metode pengambilan sampel responden menggunakan metode purposive Random sampling, dimana dari 6 (enam) kelompok tani yang ada di desa Tracap 
Kecamatan Kaliwiro dipilih peternak yang mempunyai ternak kambing minimal 2 ekor, Untuk setiap kelompok dipilih secara random 5 (lima) orang peternak sehingga di peroleh 30 responden. Jumlah ini dipilih agar dapat memenuhi syarat perhitungan statistik yang baik dengan penyebaran skor yang mendekati kurva normal. (Rahmawati, 2008).

\section{Metode Pengambilan Data}

Metode pengambilan data dalam penelitian dilakukan dengan :

observasi dan wawancara

Jenis data yang digunakan dalam penelitian adalah :

a. Data primer

Yaitu data yang diperoleh secara langsung dari peternak melalui hasil wawancara dengan menggunakan daftar pertanyaan yang telah disiapkan terlebih dahulu serta data hasil observasi. Data primer dalam penelitian ini meliputi data umur peternak responden, tingkat pendidikan responden, pengalaman beternak dan jumlah ternak yang di miliki.

b. Data sekunder

Yaitu data yang diperoleh dari sumber yang berkaitan dengan masalah yang diteliti yaitu instansi yang terkait dengan penelitian ini. Data sekunder dalam penelitian ini adalah data keadaan penduduk Desa Tracap Kecamatan Kaliwiro Kabupaten Wonosobo.

\section{Rancangan Penelitian}

Rancangan penelitian dilakukan dalam rangka pengukuran respon maupun faktorfaktor yang mempengaruhi terhadap pencegahan dan pengobatan penyakit cacing gilig pada ternak kambing di Desa Tracap Kecamatan Kaliwiro Kabupaten Wonosobo. Responden berjumlah 30 orang diambil data awal (pra test) dan pos test dengan cara melakukan wawancara langsung mengenai pencegahan dan pengobatan Penyakit cacing gilig menggunakan alat bantu kuesioner yang mana tingkatan atau jenjang setiap gejala di ukur dengan menggunakan skala likert yaitu Respon tinggi (5), Respon sedang (3) Respon rendah (1), dimana daftar pertanyaan merupakan alternatif pengungkapan permasalahan yang di dasarkan pada variabel yang diamati yaitu perubahan prilaku yang terdiri dari tiga aspek, yaitu aspek pengetahuan, sikap dan keterampilan. Faktor-faktor yang mempengaruhi respon dapat di uji menggunakan regresi linier berganda.

\section{Variabel Penelitian}

Variabel penelitian yang ingin diketahui adalah Pengetahuan, Sikap, Keterampilan (PSK) peternak terhadap pencegahan dan pengobatan penyakit cacing gilig pada ternak kambing. Untuk mengukur respon peternak terhadap pencegahan dan pengobatan penyakit cacing gilig pada ternak kambing dengan menggunakan kuesioner PSK tersebut.

\section{Analisis Data}

Analisis yang digunakan adalah analisis Deskriftif Comperatif yaitu membandingkan perubahan pengetahuan sebelum penyuluhan dan sesudah penyuluhan dengan rancangan pra eksperimental menggunakan two group Pra Test and Post Test Designs (Mardikanto, 2009). Dalam rancangan ini, pengamatan atau pengukuran di lakukan sebelum dan sesudah variabel bebas atau perlakuan di kenakan pada satu kelompok subjek yang di teliti $\left(\begin{array}{lll}\mathbf{O}_{1} & \mathbf{T} & \mathbf{O}_{2}\end{array}\right)$ dengan penjelasan sebagai berikut :

$\mathrm{O}_{1}$ : Pra test, untuk mengukur pengetahuan, sikap dan 
keterampilan sebelum kegiatan penyuluhan

$\mathrm{T}$ : Treatment, kegiatan penyuluhan

$\mathrm{O}_{2}$ : Post test, untuk mengukur pengetahuan, sikap dan keterampilan setelah diadakan kategori penyuluhan.
Berdasarkan hasil pra test dan post test di tentukan kategori penilaian dengan menggunakan skala likert yaitu jumlah skor maksimal dari setiap pertanyaan variabel ukur dikurangi jumlah skor minimal, kemudian selisihnya dibagi tiga. Dengan jumlah pertanyaan ada lima, adapun kategori dan skala yang digunakan sebagai berikut :

1. Untuk mengukur aspek pengetahuan nilai minimal (1) dan maksimal (5)

Tahu

Kurang tahu

Tidak tahu

Tidak tahu Kurang tahu $\quad$ Tahu

2. Untuk mengukur aspek sikap nilai minimal (1) dan nilai maksimal (5)

Setuju

Ragu - ragu

Kurang setuju

5

$11,6-$ 18,2

Kurang setuju

Ragu - ragu

3. Untuk mengukur aspek keterampilan nilai minimal (1) dan maksimal (5)

Terampil

Kurang terampil

Tidak terampil

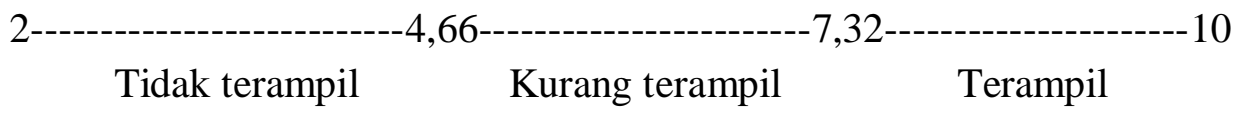

Respon adalah tanggapan atau reaksi mereka terhadap adanya tekhnologi / inovasi baru yang berupa pengetahuan (kognitif), sikap (afektif) dan keterampilan (psikomotorik). Respon diukur dari jumlah skor ketiga aspek pengetahuan, sikap dan keterampilan, skala kategori yang diukur adalah sebagai berikut :

$\begin{array}{ll}\text { Skor } 12-28 & =\text { Rendah } \\ \text { Skor } 29-44 & =\text { Sedang }\end{array}$

Skor $46-60=$ Tinggi

Skor 12 merupakan jumlah nilai terendah dari seluruh pertanyaan, skor 60 merupakan jumlah nilai tertinggi dari seluruh pertanyaan pada aspek pengetahuan sikap dan keterampilan. Untuk mendapatkan skala 12 dan 28 caranya skor tertinggi dikurang skor terendah dibagi tiga $(60-12): 3)$, hasilnya dijadikan skala.

12 28 Rendah Sedang 44 Tinggi 60

Hasil dari rekapitulasi pra test aspek pengetahuan, sikap dan keterampilan dijumlahkan, kemudian hasil dari sebelum dilakukan penyuluhan hasilnya sikap dan keterampilan setelah dilakukan 
penyuluhan juga dijumlahkan kemudian diambil nilai rata-rata. Selisih dari kenakian post test dikurang pra test dijadikan nilai respon.

Analisis regresi, merupakan analisis yang digunakan untuk menguji kesignifikan pengaruh (keseluruhan atau masing-masing) variabel-variabel bebas terhadap satu variabel terikat, yang ditunjukan pada koefisien regresinya.Maka untuk mengetahui faktor - faktor yang mempengaruhi respon digunakan analisis regresi linier berganda.

Dalam penelitian analisis regresi linier berganda dapat digunakan dalam bentuk yang model matematisnya $\mathrm{Y}=\mathrm{a}+\mathrm{b}_{1} \mathrm{X}_{1}+$ $\mathrm{b}_{2} \mathrm{X}_{2}+\mathrm{b}_{3} \mathrm{X}_{3}+\mathrm{b}_{4} \mathrm{X}_{4}+\mathrm{e}$ (Mardikanto, 2006) $\mathrm{Y}=$ Tingkat respon peternak (tinggi/sedang/rendah)

$\mathrm{X}_{1}=$ Variabel lama pendidikan $(1,2,3)$

$\mathrm{X}_{2}=$ Varabel umur peternak (thn)

$\mathrm{X}_{3}=$ Variabel pengalaman beternak (thn)

$\mathrm{X}_{4}=$ Variabel jumlah kepemilikan ternak (ekor)

$\mathrm{a}=$ Konstanta

$\mathrm{b}_{1} \quad=$ Koefisiensi regresi parsial yang menghubungkan tingkat pendidikan peternak terhadap respon pencegahan dan pengobatan

EP $=\frac{\text { Skor Post Test }}{\text { Nilai Maksimum }} \times 100 \%$

0 $33,3 \%$ Kurang efektif penyakit cacing gilig pada ternak kambing.

$b_{2}=$ Koefisiensi regresi parsial yang menghubungkan umur peternak terhadap respon pencegahan dan pengobatan penyakit cacing gilig pada ternak kambing.

$\mathrm{b}_{3}=$ Koefisiensi regresi parsial yang menghubungkan pengalaman beternak terhadap respon pencegahan dan pengobatan penyakit cacing gilig pada ternak kambing.

$\mathrm{b}_{4} \quad=$ Koefisiensi regresi parsial yang menghubungkan jumlah kepemilikanternak terhadap respon pencegahan dan pengobatan penyakit cacing gilig pada ternak kambing.

e $\quad=$ Faktor-faktor diluar persamaan .

Efektifitas penyuluhan (EP) dan Efektifitas perubahan Perilaku (EPP) dihitung untuk mengetahui hasil kegiatan penyuluhan dengan rumus :

Adapun kriteria yang digunakan dalam skala sabagai berikut :
a. Skor $0-33,33 \%$
: Kurang efektif
b. Skor $33,34 \%-66,66 \%$
: Cukup efektif
c. Skor $66,67 \%-100 \%$
: Efektif

(Ginting, 1994). 


\section{HASIL DAN PEMBAHASAN}

\section{Respon Responden}

Hasil respon peternak terhadap pencegahan dan pengobatan penyakit cacing gilig pada ternak kambing setelah dilakukan penyuluhan mendapatkan hasil sebagai berikut :

1. Tingkat Respon Responden Pada Aspek Pengetahuan

Nilai aspek pengetahuan sebelum dan sesudah dilakukan penyuluhan dapat dilihat pada tabel 1 berikut ini :

Tabel 1. Nilai aspek pengetahuan

\begin{tabular}{clccc}
\hline No & Pertanyaan & Pra test & Post test & Peningkatan \\
\hline \multirow{2}{*}{1} & Pengertian penyakit cacing gilig & 1,46 & 4,93 & 3,47 \\
2 & Tanda - tanda penyakit cacing gilig & 1,26 & 4,46 & 3,2 \\
3 & Cara pencegahan penyakit cacing gilig & 1 & 4,06 & 3,06 \\
& $\begin{array}{l}\text { Cara memberikan obat cacing pada } \\
\text { ternak kambing }\end{array}$ & 1 & 3,6 & 2,6 \\
5 & $\begin{array}{l}\text { Cara mengobati penyakit cacing gilig } \\
\text { dengan menggunakan obat tradisional }\end{array}$ & 1,06 & 3,6 & 2,54 \\
& (serbuk buah pinang) & & & \\
\hline & Jumlah & $\mathbf{5 , 7 8}$ & $\mathbf{2 0 , 6 5}$ & $\mathbf{1 4 , 8 7}$ \\
\hline & Rata -rata & $\mathbf{1 , 1 5 6}$ & $\mathbf{4 , 1 3}$ & $\mathbf{2 , 9 7 4}$ \\
\hline \hline
\end{tabular}

Sumber Data Primer Terolah 2012

$01(5,78)$

5--x-

Tidak tahu
$-11,6-$

O2 $(20,65)$

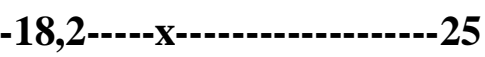

Kurang tahu Tahu

$\mathbf{O 1}=$ Pra test $(5,78)$

$\mathbf{O 2}=$ Post test $(20,65)$

Perhitungan EP dan EPP pada aspek pengetahuan

$$
\begin{aligned}
\text { EP } & =\frac{\text { Skor Post Test }}{\text { Nilai Maksimum }} \\
& =\frac{20,65 \times 100 \%}{25} \times 100 \% \\
& =82,, 6 \% \\
\text { EPP } & =\frac{\text { Skor Post Test }- \text { Skor Pra test }}{\text { Skor Maksimum }- \text { Skor Pra test }} \times 100 \% \\
\text { EPP } & =\frac{20,65-5,78}{25-5,78} \times 100 \% \\
& =77,36 \%
\end{aligned}
$$

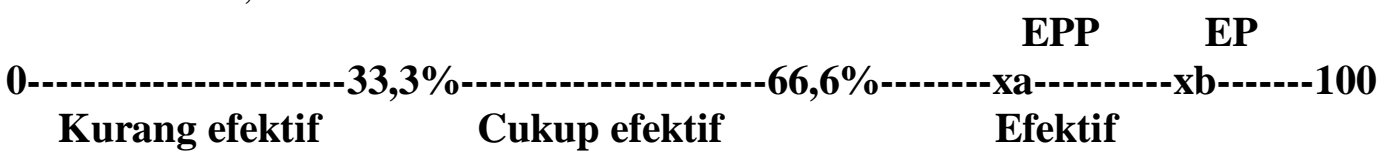

Keterangan : $x a=$ EPP 77,36\% (Efektif $)$

$$
\mathrm{xb}=\mathrm{EP} 82,6 \% \text { (Efektif) }
$$


Berdasarkan tabel 1 diatas dapat diketahui pada aspek pengetahuan saat dilakukan pra test memiliki nilai sebesar 5,78 (tidak tahu), setelah dilakukan treatmen pada nilai post test menjadi 20,65 (tahu). Dengan demikian terjadi peningkatan sebesar 14,87 atau dari tidak tahu menjadi tahu, hal ini di sebabkan oleh tingkat pendidikan peternak dimana semua responden rata-rata sudah mengenyam bangku sekolah sehingga memungkinkan mereka untuk dapat menyerap ilmu pengetahuan dengan baik. Hal ini sesuai pendapat Mardikanto (2006) bahwa tingkat pendidikan yang dimiliki seseorang akan berpengaruh terhadap kapasitas/kemampuan belajar yang memerlukan tingkat pengetahuan tertentu untuk dapat memahami suatu teknologi/inovasi.

Peningkatan aspek pengetahuan peternak tersebut juga disebabkan oleh kesesuaian materi penyuluhan yang diberikan menggunakan metode ceramah, diskusi dan demontrasi cara dengan menggunakan alat bantu berupa folder, EK sehingga para petani lebih mudah memahami apa yang disampaikan. Sesuai dengan pendapat Mardikanto (2006) bahwa, dalam penyampaian penyuluhan tidak hanya dengan lisan, tetapi juga perlu alat bantu atau alat peraga agar materi lebih mudah diterima dan diserap serta lebih mengesankan.

Dari hasil analisis Pra Test dan Post Test pada aspek pengetahuan responden diketahui EP 82,6 \% dinyatakan efektif dan EPP 77,36 dinyatakan efektif. Efektifitas Penyuluhan untuk merubah perilaku aspek pengetahuan sebesar 82,6 \% di katakan efektif, hal ini berarti kegiatan penyuluhan yang dilakukan dengan materi pencegahan dan pengobatan penyakit cacing gilig pada ternak kambing, dengan metode pendekatan individu dan kelompok dan dengan teknik ceramah, diskusi, serta demonstrasi cara dapat berkesan / berpengaruh terhadap perubahan aspek pengetahuan petani dari sebelum dilakukan penyuluhan dengan nilai 5,78 dan setelah diberi penyuluhan meningkat menjadi 20,65. Efektifitas Perubahan Perilaku aspek pengetahuan sebesar 77,36 \% dikatakan efektif dimana sasaran penyuluhan dapat menerima dengan baik materi yang diberikan dalam penyuluhan tersebut. Hal ini dapat dilihat dari perubahan pengetahuan dari sebelum dan sesudah dilakukan penyuluhan. Menurut Ginting (1994), pada dasarnya dalam setiap tahap dilakukan evaluasi ataupun pemantauan dengan tujuan untuk mengadakan perbaikan selama proses berlangsung. Dalam kegiatan ini peternak diikutsertakan agar mereka mengetahui tingkat perubahan yang telah terjadi atau sejauh mana efektifitas penyuluhan dan efektifitas pengetahuan, sikap, dan keterampilan yang dapat dicapai.

Peningkatan aspek pengetahuan peternak tersebut juga disebabkan karena dalam kegiatan penyuluhan menggunakan teknik ceramah, diskusi dan demostrasi cara dengan menggunakan alat bantu berupa folder dan EK sehingga para peternak lebih mudah memahami apa yang disampaikan. Sesuai dengan pendapat Mardikanto (2006) bahwa dalam penyampaian penyuluhan tidak hanya dengan lisan, tetapi juga perlu alat bantu atau alat peraga agar materi lebih mudah diterima dan diserap serta lebih mengesankan.

\section{Tingkat Respon Responden Pada Aspek Sikap}

Nilai aspek sikap sebelum dan sesudah dilakukan penyuluhan dapat dilihat pada tabel 2 berikut ini : 
Tabel 2. Nilai aspek sikap

\begin{tabular}{clccc}
\hline No & \multicolumn{1}{c}{ Pertanyaan } & Pra test & Post test & Peningkatan \\
\hline 1 & Membersihkan kandang secara periodik & 2,13 & 4,6 & 2,47 \\
2 & $\begin{array}{l}\text { Memberikan obat cacing monil untuk } \\
\text { pencegahan penyakit cacing gilig }\end{array}$ & 2,53 & 4,73 & 2,2 \\
3 & $\begin{array}{l}\text { Kambing sakit cacing gilig memanggil } \\
\text { petugas keswan } \\
4\end{array}$ & 2,26 & 4 & 1,74 \\
$\begin{array}{l}\text { Mencari rumput setelah pukul 09.00 } \\
\text { WIB }\end{array}$ & 2,6 & 4,46 & 1,86 \\
& $\begin{array}{l}\text { Menggunakan obat cacing tradisional } \\
\text { (serbuk buah pinang) untuk mengobati } \\
\text { penyakit cacing gilig }\end{array}$ & 2,73 & 4,93 & 2,2 \\
\hline & Jumlah & $\mathbf{1 2 , 2 5}$ & $\mathbf{2 2 , 7 2}$ & $\mathbf{1 0 , 4 7}$ \\
\hline Rata - rata & $\mathbf{2 , 4 5}$ & $\mathbf{4 , 5 4 4}$ & $\mathbf{2 , 0 9 4}$ \\
\hline
\end{tabular}

Sumber Data Primer Terolah 2012

\section{$01(12,25) \quad 02(22,72)$}

Kurang setuju $\quad$ Ragu - ragu
$\mathrm{O} 1=$ Pra Test $(12,25)$

Perhitungan EP dan EPP pada aspek sikap

$$
\begin{aligned}
\mathrm{EP} & =\frac{\text { Skor Post Test__ }}{\text { Nilai Maksimum } 100 \%} \\
& =\frac{22,72 \times 100 \%}{25} \\
& =90,88 \% \\
\mathrm{EPP} & =\frac{\text { Skor Post Test }- \text { Skor Pra test__ }}{\text { Skor Maksimum }- \text { Skor Pra test }} 100 \% \\
\mathrm{EPP} & =\frac{22,72-12,25}{25-12,25} \times 100 \% \\
& =82,12 \%
\end{aligned}
$$

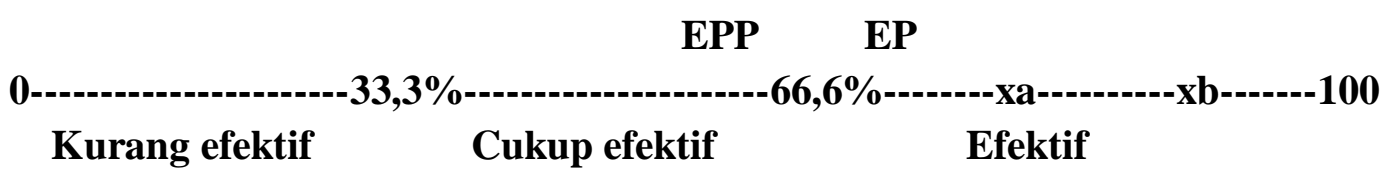

Keterangan : $\mathrm{xa}=\mathrm{EPP} 82,12 \%$ (Efektif)

$\mathrm{xb}=\mathrm{EP} \quad 90,88 \%$ (Efektif)

Melihat tabel 2 diatas dapat dilihat 22,72 dengan kategori respon setuju. nilai pra test pada aspek sikap menunjukkan Berdasarkan hasil analisis pra test dan post nilai 12,25 dengan kategori respon setuju, test terjadi peningkatan nilai sebesar 10,47 sedangkan hasil post test menunjukkan nilai hal ini disebabkan oleh adanya kegiatan 
penyuluhan yang tepat sasaran dalam arti baik materi maupun metode yang diberikan sesuai dengan kebutuhan peternak yaitu materi tentang pencegahan dan pengobatan penyakit cacing gilig pada ternak kambing dengan metode ceramah, diskusi dan demontrasi cara alat bantu yang digunakan berupa folder, EK (elemen ketrampilan) sehingga para petani lebih mudah memahami apa yang disampaikan, hal ini sesuai dengan pendapat Mardikanto dan Sutarni (2006), bahwa penyuluhan pertanian yang terutamakan ditujukan kepada petani dan keluarganya pada dasarnya dimaksudkan untuk mengubah dalam arti dapat meningkatkan perilakunya mengenai sikap yang lebih progresif dan motifasi yang lebih rasional.

Dari hasil analisis Pra Test dan Post Test pada aspek sikap responden diketahui EP 90,88 \% dinyatakan efektif, berarti bahwa program penyuluhan dengan materi pencegahan dan pengobatan penyakit cacing gilig pada ternak kambing dengan metode pendekatan individu dan kelompok serta dengan teknik ceramah, diskusi dan demonstrasi cara dapat berpengaruh dan berdampak bagi perubahan sikap petani terhadap teknologi pencegahan dan pengobatan penyakit cacing gilig pada ternak kambing dapat dilihat dari aspek sikap sebelum dan sesudah dilakukan penyuluhan dari ragu - ragu (nilai 12,25) menjadi setuju (nilai 22,72). Efektifitas Perubahan Perilaku sebesar 82,12 adalah efektif berarti penyuluhan yang dilaksanakan membawa perubahan bagi sikap peternak dari ragu ragu dalam menerima teknologi pencegahan dan pengobatan penyakit cacing gilig pada ternak kambing (nilai 12,25) menjadi setuju (nilai 22,72) dan berarti respon petani tinggi. Menurut Ginting (1993), pada dasarnya dalam setiap tahap dilakukan evaluasi ataupun pemantauan dengan tujuan untuk mengadakan perbaikan selama proses berlangsung. Dalam kegiatan ini peternak diikutsertakan agar mereka mengetahui tingkat perubahan yang telah terjadi atau sejauh mana efektifitas penyuluhan dan efektifitas pengetahuan, sikap, dan keterampilan yang dapat dicapai.

\section{Responden Pada Aspek Keterampilan}

Nilai aspek keterampilan sebelum dan sesudah dilakukan penyuluhan dapat dilihat pada tabel 3 berikut ini :

Tabel 3. Nilai aspek keterampilan

\begin{tabular}{clccc}
\hline No & \multicolumn{1}{c}{ Pertanyaan } & Pra test & Post test & Peningkatan \\
\hline \hline 1 & $\begin{array}{l}\text { Pemberian obat cacing pada } \\
\text { ternak dengan menggunakan } \\
\text { obat cacing monil }\end{array}$ & 1,3 & 4,13 & 2,83 \\
2 & $\begin{array}{l}\text { Cara apabila obat cacing monil } \\
\text { susah di telan }\end{array}$ & 2,26 & 4,53 & 2,27 \\
& Jumlah & $\mathbf{3 , 5 6}$ & $\mathbf{8 , 6 6}$ & $\mathbf{5 , 1}$ \\
\hline Rata -rata & $\mathbf{1 , 7 8}$ & $\mathbf{4 , 3 3}$ & $\mathbf{2 , 5 5}$ \\
\hline \hline
\end{tabular}

Sumber data primer terolah 2012

$01(3,56)$

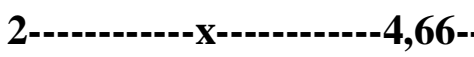

Tidak terampil

\section{Kurang terampil}

$02(8,66)$

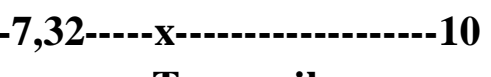

Terampil 
Perhitungan EP dan EPP pada aspek sikap

$$
\begin{aligned}
& \mathrm{EP}=\frac{\text { Skor Post Test__ }}{\text { Nilai Maksimum }} \times 100 \% \\
& =8,66 \times 100 \% \\
& 10 \\
& =86,6 \% \\
& \mathrm{EPP}=\frac{\text { Skor Post Test }- \text { Skor Pra test__ }}{\text { Skor Maksimum }- \text { Skor Pra test }} 100 \% \\
& \mathrm{EPP}=\underline{8,66-3,56} \times 100 \% \\
& 10-3,56 \\
& =79,19 \%
\end{aligned}
$$

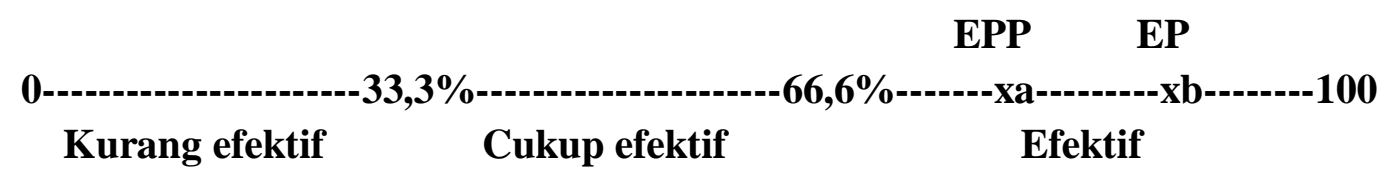

$$
\text { Keterangan : } \begin{aligned}
\mathrm{xa} & =\mathrm{EPP} 79,19 \%(\text { Efektif }) \\
\mathrm{xb} & =\mathrm{EP} 86,6 \%(\text { Efektif })
\end{aligned}
$$

Melihat tabel 3 diatas dapat dilihat nilai pra test pada aspek keterampilan menunjukkan nilai 3,56 dengan kategori respon kurang terampil, sedangkan hasil post test menunjukkan nilai 8,66 dengan kategori respon terampil. Berdasarkan hasil analisis pra test dan post test terjadi perubahan peningkatan nilai sebesar 5,1 atau dari kategori kurang trampil menjadi trampil. Hal ini disebabkan oleh adanya dampak dari kegiatan penyuluhan yang telah diberikan khususnya demonstrasi cara pemberian obat cacing sehingga peternak dapat melihat dan mempraktekan secara langsung pemberian obat cacing pada ternak kambing tersebut. Hal ini sesuai dengan pendapat Kartasapoetra (1988) mengatakan bahwa pengukuran aspek keterampilan dipengaruhi beberapa faktor berikut : a. Metode penyuluhan adalah pendekatan kelompok biasanya lebih efektif dan lebih bermanfaat apabila dilakukan terhadap kelompok tani.
Dimana petani diajak dan dibimbing serta diarahkan untuk melakukan kegiatan yang lebih preduktif atas dasar kerjasama. b. Teknik penyuluhan. Teknik penyuluhan yang digunakan adalah ceramah dan diskusi dan demcar dengan demikian petani ikut berpartisipasi petani akan lebih memahami materi yang disampaikan. Selanjutnya menurut Mardikanto (2006), bahwa dengan petani melihat sendiri mereka akan lebih percaya dengan penyuluhan yang kita berikan dan dengan kepercayaan tersebut mereka akan terdorong untuk melakukan tindakan terhadap inovasi baru yang diterima.

Dari hasil analisis Pra Test dan Post Test pada aspek keterampilan responden diketahui EP 86,6 \% dinyatakan efektif berarti program penyuluhan yang telah dilakukan dapat berdaya guna karena dapat merubah keterampilan dari tidak terampil menjadi trampil. EPP 79,19 dinyatakan 
efektif dapat dilihat dari peningkatan perubahan aspek ketrampilan peternak dari tidak trampil memberikan obat cacing pada ternak kambing menjadi trampil.

\section{Peningkatan nilai respon.}

Nilai respon sebelum dan sesudah dilakukan penyuluhan dapat dilihat pada tabel 4 berikut ini :

Tabel 4. Nilai respon

\begin{tabular}{llcc}
\hline \hline Nilai & Jumlah (orang) & Post test & Persentase (\%) \\
\hline Pengetahuan & 5,8 & 20,66 & 12,54 \\
Sikap & 12,26 & 22,73 & 4,4 \\
Keterampilan & 3,6 & 8,66 & 3,66 \\
& & & 30,39 \\
\hline Jumlah & 21,66 & 52,05 &
\end{tabular}

Sumber : Data primer terolah 2012

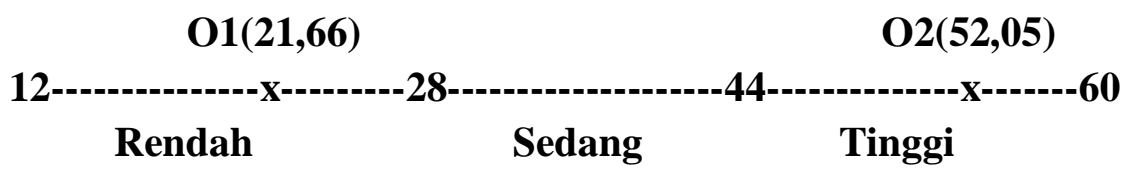

Berdasarkan tabel diatas dapat diketahui nilai respon saat dilakukan pra test memiliki nilai sebesar 21,66 atau (Nilai rendah), setelah dilakukan treatmen pada nilai post test menjadi 52,05 atau (Nilai tinggi). Dengan demikian terjadi peningkatan sebesar 30,39 atau dari respon rendah menjadi respon tinggi, untuk lebih jelasnya dapat dilihat pada lampiran . Hal ini di sebabkan oleh :

a. Tingkat pendidikan peternak dimana semua responden rata-rata sudah mengenyam bangku sekolah sehingga memungkinkan mereka untuk dapat menyerap ilmu pengetahuan dengan baik. Hal ini sesuai pendapat Mardikanto (2006) bahwa tingkat pendidikan yang dimiliki seseorang akan berpengaruh terhadap kapasitas/kemampuan belajar yang memerlukan tingkat pengetahuan tertentu untuk dapat memahami suatu teknologi/inovasi. Selanjutnya Padmowiharjo (2002), menyatakan bahwa, semakin tinggi tingkat pendidikan petani maka pola pikir juga semakin luas dan tentunya akan lebih cepat dalam merespon teknologi baru yang disampaikan.

b. Umur responden terbanyak adalah 36 - 49 tahun dengan persentase $43,33 \%$ yang merupakan umur produktif, karena umur responden sangat mempengaruhi respon petani. Junaidi (2007) Semakin tinggi umur semakin sulit baginya untuk menyerap dan menerima suatu inovasi yang diberikan. Usia $15 \mathrm{~s} / \mathrm{d} \quad 65$ tahun dikatakan penduduk usia produktif adalah yang melaksanakan produksi dari segi ekonomi, dimana segala kebutuhannya ditanggung mereka sendiri, sedangkan penduduk usia tidak produktif adalah penduduk yang belum bisa bekerja atau tidak mampu lagi memenuhi akan kebutuhan hidupnya sendiri. 
(Kependudukan kantor informasi dan komunikasi pemerintah Propinsi Jawa Tengah, 2004).

c. Pengalaman beternak responden rata-rata 4 - 12 tahun, sehingga diharapkan dengan pengalaman yang cukup tinggi maka tingkat respon terhadap pencegahan dan pengobatan penyakit cacing gilig juga semakin tinggi. Junaidi (2007) menyatakan bahwa, pengalaman merupakan faktor personal yang berpengaruh terhadap perilaku seseorang.

d. Kepemilikan ternak rata - rata peternak mempunyai ternak lebih dari satu ekor ini terlihat dari jumlah kepemilikan ternak responden yaitu $2-4$ ekor sebanyak 14 orang atau $(46,66 \%)$. Iswandari (2006) menyatakan bahwa, peternak yang memiliki ternak dengan jumlah banyak dan dikelola sendiri akan mempunyai kemauan yang tinggi dalam merespon, memperbaiki usaha tani ternaknya guna meningkatkan hasil dan pendapatannya untuk memenuhi kebutuhan sehariharinya.

e. Peningkatan respon peternak tersebut mungkin karena kesesuaian materi penyuluhan yang diberikan menggunakan metode ceramah, diskusi dan demontrasi cara dengan menggunakan alat bantu berupa folder, EK sehingga para peternak lebih mudah memahami apa yang disampaikan. Sesuai dengan pendapat Mardikanto (2006) bahwa, dalam penyampaian penyuluhan tidak hanya dengan lisan, tetapi juga perlu alat bantu atau alat peraga agar materi lebih mudah diterima dan diserap serta lebih mengesankan.

\section{Uji Statistik}

\section{Analisis Regresi}

Berdasarkan analisis regresi didapatkan persamaan linear berganda sebagai berikut : $\mathrm{Y}=28.946+5.084 \mathrm{X} 1-$ $0,215 \mathrm{X} 2+0,171 \mathrm{X} 3+0,548 \mathrm{X} 4+\mathrm{e}$

Dari model regresi diatas dapat di artikan bahwa setiap peningkatan nilai X1 (pendidikan) sebesar $1 \%$ akan menambah nilai respon sebesar 5.084, setiap peningkatan nilai X2 (umur) sebesar $1 \%$ akan mengurangi nilai respon sebesar 0,215 , setiap peningkatan nilai X3 (pengalaman beternak) sebesar $1 \%$ akan menambah nilai respon sebesar 0,171 dan setiap peningkatan nilai X4 (jumlah kepemilikan ternak) sebesar $1 \%$ akan menambah nilai respon sebesar 0,548 .

\section{a. Uji Determinasi $\left(\mathbf{R}^{2}\right)$}

Berdasarkan Uji Determinasi (Adjujusted R Square), untuk menentukan sejauh mana pendidikan, umur, pengalaman dan jumlah kepemilikan ternak secara bersama - sama mempengaruhi respon peternak terhadap inovasi teknologi pencegahan dan pengobatan penyakit cacing gilig pada ternak kambing sebesar 47,4\% (Adjusted $\mathrm{R}^{2}=0,474$ ) sedangkan 52,6\% dipengaruhi oleh faktor-faktor lain diluar persamaan. Semakin besar $R^{2}$ (mendekati 1) semakin baik hasil regresi tersebut (semakin besar variabel independen dapat menjelaskan variabel dependen dan semakin mendekati 0 maka variabel independen secara keseluruhan semakin kurang bisa menjelaskan variabel dependen (Mubyarto, 1999).

\section{b. Uji F /ANOVA}


Dilihat dari ANOVA, signifikansinya $0,000 \alpha(\mathrm{P} \leq 0,01)$, hal ini berarti bahwa pengaruh umur, pendidikan, pengalaman beternak dan jumlah kepemilikan ternak secara bersama - sama berpengaruh sangat signifikan terhadap respon peternak terhadap pencegahan dan pengobatan penyakit cacing gilig.

\section{c. Uji T}

Nilai konstanta sebesar 28.946 menyatakan bahwa jika tidak ada variabel independen, secara statistik nilai $\mathrm{x}_{1}, \mathrm{x}_{2}, \mathrm{x}_{3}$, dan $\mathrm{x}_{4}$ adalah 0 maka nilai respon peternak adalah 28.946 dengan nilai signifikan 0,000 yang artinya berpengaruh sangat signifikan terhadap respon. Untuk mengetahui secara parsial masing - masing variabel terhadap variabel terkait, maka dapat digunakan uji t dengan hasil sebagai berikut :

1) Pendidikan

Variabel pendidikan berpengaruh sangat signifikan terhadap respon dengan $\alpha(\mathrm{P} \leq 0,01)$. Nilai koefisien regresi dari variabel pendidikan adalah 0,001 berpengaruh sangat signifikan terhadap respon, hasil yang positif ini dikarenakan rata-rata pendidikan responden di Desa Tracap sebagian besar lulus Sekolah Dasar sehingga dapat membaca dan menulis. Mardikanto (2009) menyatakan bahwa tingkat pendidikan yang dimiliki seseorang akan berpengaruh terhadap kapasitas/kemampuan belajar yang memerlukan tingkat pengetahuan tertentu untuk dapat memahami suatu teknologi/inovasi.

2) Umur

Variabel umur berpengaruh signifikan $\alpha(\mathrm{P} \leq 0,05)$ terhadap respon dengan tingkat signifikansi
0,011 dan berpengaruh secara negatif ( - ) artinya ada kecenderungan semakin tinggi umur peternak maka semakin rendah pula respon peternak terhadap inovasi teknologi pencegahan dan pengobatan penyakit cacing gilig pada ternak kambing. Hal ini sesuai dengan pendapat Mardikanto (2009) yang menyatakan bahwa umur 50 tahun keatas memiliki daya serap dan pemahaman yang kurang atau kurang merespon inovasi baru.

3) Jumlah ternak dan pengalaman beternak

Variabel pengalaman beternak dan jumlah ternak tidak berpengaruh signifikan terhadap respon. Hal ini disebabkan karena respon petani lebih banyak dipengaruhi oleh faktor-faktor selain variabelvariabel tersebut. Mardikanto (2009) mengemukakan ada beberapa faktor yang mempengaruhi kecepatan seseorang untuk merespon meliputi (1). Luas usaha tani, semakin luas usaha taninya biasanya semakin cepat merespon, karena memiliki kemampuan ekonomi yang lebih baik. (2). Tingkat pendapatan semakin tinggi pendapatan biasanya akan semakin merespon inovasi. (3). Keberanian mengambil resiko, sebab pada tahap awal biasanya tidak selalu berhasil seperti yang diharapkan. Karena itu, individu yang memiliki keberanian menghadapi resiko biasanya lebih inovatif.

(4). Tingkat partisipasinya dalam kelompok/organisasi diluar 
lingkungannya sendiri, umumnya lebih inovatif dibandingkan mereka yang hanya melakukan kontak pribadi dengan warga masyarakat setempat.

Aktivitas mencari informasi dan ide-ide baru biasanya lebih inovatif dibandingkan dengan orang-orang yang pasif apalagi yang selalu tidak percaya terhadap sesuatu yang baru.

\section{KESIMPULAN DAN SARAN}

\section{Kesimpulan}

Hasil kajian respon peternak yang diukur melalui perubahan perilaku pada penelitian ini dapat disimpulkan sebagai berikut :

1. Tingkat respon peternak terhadap pencegahan dan pengobatan penyakit cacing gilig pada ternak kambing meningkat dari respon rendah $(21,66)$ menjadi respon tinggi $(52,05)$.

2. Faktor pendidikan berpengaruh sangat signifikan terhadap respon dengan nilai signifikansi $0,001, \alpha(\mathrm{P} \leq 0,01)$, dan umur berpengaruh signifikan terhadap nilai respon dengan nilai signifikansinya $0,011 \alpha(\mathrm{P} \leq 0,05)$, sedangkan secara bersama - sama faktor pendidikan, umur, pengalaman beternak, jumlah ternak, berpengaruh sangat signifikan terhadap peningkatan respon, dengan nilai signifikansinya $0,000 \alpha(\mathrm{P} \leq 0,01)$.

\section{Saran}

Berdasarkan hasil penelitian disarankan :

1. Perlu sosialisasi lebih lanjut tentang pencegahan dan pengobatan penyakit cacing gilig pada ternak kambing.
2. Perlu dilakukan pembinaan yang berkelanjutan dari dinas atau instansi terkait untuk terus dapat meningkatkan pengetahuan, sikap, dan ketrampilan petani dalam rangka peningkatan usahatani.

\section{DAFTAR PUSTAKA}

Ginting, E. 1994. Pokok Pikiran Penerapan Metode Penelitian Sosial dalam Program Kuliah Kerja Lapang. Universitas Brawijaya, Malang.

Iswandari. 2006. Respon Petani Terhadap Pasca Panen Ubi Kayu di Kecamatan Playen Kabupaten Gunung Kidul. Skripsi Fakultas Pertanian UGM Yogyakarta.

Junaidi. 2007. Pemahaman tentang Adopsi, Difusi dan Inovasi (Teknologi) dalam Penyuluhan Pertanian.

http://database.deptan.go.id:8081/portalpeny uluhan

Kantor informasi dan komunikasi pemerintah propinsi jawa tengah tahun 2004

http://www.google.com/search?q=kependud ukan+kantor+informasi+dan+komuni kasi+pemerintah+provinsi+jawa+teng ah\&hl=en\&prmd=ivns\&ei=RO

Kartasapoetra. 1988. Metodologi Penelitian Sosial dan Pendidikan TeoriAplikasi. Bumi Aksara. Jakarta

Mardikanto,T. 2006. Prosedur Penelitian Untuk Penyuluhan Pembangunan dan Pemberdayaan Masyarakat. Prima Theresia Pressindo. Surakarta.

Mardikanto,T.2009. Sistem Penyuluhan Pertanian. Lembaga pengembangan pendidikan (LPP) UNS dan Pencetakan (UNS Press). Surakarta. 
Mubyarto, 1999. Reformasi Sistem Ekonomi dari Kapitalisme Menuju Ekonomi Kerakyatan. Aditia Media Yogyakarta.

Padmowihardjo, S. 2002. Metode Penyuluhan Pertanian. Universitas

Terbuka. Jakarta.

Subekti, S, S. Mumpuni, S. Koesdarto dan H. Puspitawati. 1996. Ilmu Penyakit Nematoda. Fakultas Kedokteran Hewan. Universitas Airlangga. Surabaya.

Suryabrata. 2005. Psikologi Pendidikan. Raja Grafindo persada. Jakarta. 